\title{
Comparison of Production Levels and Rice Farming Income Using Technology And Corporate Farming (Case Study In Gapoktan Tani Mandiri Dalangan Village, Tawangsari District, Sukoharjo Regency, Central Java)
}

\author{
Ayuda Werti ${ }^{1 *}$, Djoko Koestiono², Abdul Wahib Muhaimin ${ }^{3}$ \\ ${ }^{1}$ Postgraduate, Agribusiness Study Program, Faculty of Agriculture, Brawijaya University, Veteran St., \\ Malang (65145), Indonesia \\ ${ }^{2,3}$ Department of Socio Economics, Faculty of Agriculture, Brawijaya University, Veteran St., Malang \\ (65145), Indonesia
}

Received: 28 May 2019; Revised: 17 November 2020; Accepted: 23 November 2020

\begin{abstract}
ABSTRAK
This study aims to analyze the comparison of the level of production and income of rice farming using technology and corporate farming at Gapoktan Tani Mandiri in Dalangan Village, Tawangsari District, Sukoharjo Regency, Central Java. The analysis used is quantitative analysis which is used to analyze the comparison of the level of production and income of rice farming using technology and corporate farming. Based on the results of the study, there was a significant increase in production yield from before using corporate farming systems and systems (Second Planting Season 2014), which amounted to $6670 \mathrm{~kg} / \mathrm{ha}$ after using technology and corporate farming systems (Second Planting Season 2018) of $8675 \mathrm{Kg} / \mathrm{ha}$, which accompanied by a reduction in production costs by $13 \%$. So there is a significant increase in income from before using corporate farming systems and technology (Second Planting Season 2014) of Rp. 17,546,541/ha after using corporate farming technology and systems (Second Planting Season 2018) reached Rp. 28,046,417/ha.
\end{abstract}

Keywords: production; revenue; technology; corporate farming

How to Cite:

Werti, A., Koestiono, D., \& Muhaimin, A. W. (2020). Comparison of Production Levels and Rice Farming Income Using Technology And Corporate Farming ( Case Study In Gapoktan Tani Mandiri Dalangan Village, Tawangsari District, Sukoharjo Regency, Central Java ). HABITAT, 31(3), 144-148. https://doi.org/10.21776/ub.habitat.2020.031.3.17

\section{Introduction}

Rice is a strategic food that has received special attention. The problems faced include rice productivity which tends to stagnate and even decline. This is caused by irrigation, seeds, fertilizers, narrow land, scarcity of labor, and agricultural machinery. The Ministry of Agriculture has set a target of food selfsufficiency, especially rice in the next three years (BALITBANG, 2015).

According to Miarso (2007: 62) technology is a process that increases added value, the process uses or produces a product, the resulting product is inseparable from other existing products, and

"Correspondence Author.

E-mail: ayuda0507@gmail.com

Telp: +62-813-3509-5431 therefore becomes an integral part of a system. Meanwhile, according to Mardikanto (1993), technology is a behavior of new products, information and practices that are not widely known, accepted, used or applied to some members of the community in a certain location in order to encourage individual change and / or all members of the community concerned. Technology that has an important role and is needed in efforts to increase rice production is a technology that can mobilize farmers to increase their rice production, while the technology in question is technology to increase land fertility, technology to minimize crop loss, and new superior varieties (Subarna, 2013).

Corporate Farming is a form of economic cooperation from a group of farmers with an agribusiness orientation through the consolidation of land management on a stretch of land while 
ensuring land ownership for each farmer, so that business efficiency, quality standardization, and effectiveness and efficiency of resource use management can be achieved (Dinas Pertanian, 2000). The long-term goal of developing corporate farming is to create an independent, competitive and sustainable farming business through corporate land management. The approach in its development is agribusiness-based rural development by optimally utilizing resource opportunities and community institutions (Setiawan, 2008).

One of the solutions offered to overcome the above problems is the application of modern agriculture (PPM) using technology (alsintan), starting from tillage, planting to harvesting and threshing. Amount and type are according to site specific needs and requests from beneficiaries. So that the application of technology (alsintan) can also overcome the problem of scarcity of labor needed in doing business. In an effort to increase production using technology (alsintan), it will run more optimally if it is applied to a wider stretch of agricultural land. For this reason, a strong farmer organization is needed, which can protect the interests of farmers in an effort to increase business productivity and their approach, so that in the end they have good food security. the Corporate Farming system is an institutional solution suitable for these conditions.

This study aims to analyze the comparison of the level of production and income of rice farming using technology and corporate farming at Gapoktan Tani Mandiri, Dalangan Village, Tawangsari District, Sukoharjo Regency, Central Java.

\section{Research Method}

The research location was determined intentionally, namely in the village of Dalangan, Tawangsari District, Sukoharjo Regency, Central Java. The location selection consideration is carried out in the area where there are farmers who cultivate rice with the application of modern agriculture (PPM) using technology (alsintan) and corporate farming and are supported by land consolidation.

The scope of the population in this study were rice farmers in Gapoktan Tani Mandiri in Dalangan Village, Tawangsari District, Sukoharjo Regency, Central Java. Gapoktan Tani Mandiri consists of four farmer group areas, namely Ngudi Rejeki, Ngudi Mulyo, Asri Rata, and Ngudi Rahayu with a total of 293 farmers. The sampling method used simple random sampling in sampling. The number of samples taken from a population of 293 was $30(10 \%)$ farmers from representatives of the four farmer group areas in the Independent Farmer Association (Arikunto, 2010: 134).

The research data used to answer problems was obtained through interviews and observations, as well as direct observation to support the completeness of information obtained through interviews. In addition, it is also obtained from various agencies or offices as well as print media related to research problems.

The analysis used is quantitative analysis which is used to analyze the cost of rice farming income, and analysis of the Paired Sample t-Test to analyze the comparison of production and income.

\section{Results and Discussion}

\subsection{Rice Farming Analysis}

Before discussing the cost component, there is also a component of the use of physical inputs in rice farming that affects the amount of production costs incurred. The number of inputs used is described in the following table.

Tabel 1. Average Physical Inputs of Rice Farming Season 2 of 2014 and Planting Season 2 of 2018 at Gapoktan Tani Mandiri

\begin{tabular}{llll}
\hline & & \multicolumn{2}{c}{ Hectares } \\
\cline { 3 - 4 } No. & Input Description & $\begin{array}{l}\text { Planting } \\
\text { Season } \\
\text { of 2014 }\end{array}$ & $\begin{array}{l}\text { Planting } \\
\text { Season 2 } \\
\text { of 2018 }\end{array}$ \\
\hline 1 & Seed (kg) & 63 & 55 \\
2 & Fertilizer & & \\
& a. Urea (kg) & 250 & 250 \\
& b. Ponska (kg) & 250 & 250 \\
& c. SP36 (kg) & 200 & 200 \\
3 & Pesticide & 1,4 & 0,9 \\
& a. Sitop (lt) & 1,3 & 0,6 \\
& b. Score250 EC (lt) & 1,4 & 0,9 \\
4 & c. Matador (lt) & & \\
Labor & a. Tillage (hok) & 15 & 15 \\
& b. Planting (hok) & 25 & 12 \\
& c. Fertilization (hok) & 3 & 3 \\
d. Weeding (hok) & 17 & 17 \\
& e. Spraying (hok) & 3 & 3 \\
& f. Harvest (hok) & 25 & 22 \\
\hline
\end{tabular}

There are differences in the use of farm physical inputs before using the technology and corporate farming system (Planting Season 2 of 
2014) and after using the technology and corporate farming system (Planting Season 2 of 2018). In Planting Season 2 of 2018 the number of seeds used decreased by $8 \mathrm{~kg} / \mathrm{ha}$, this is because planting with alsintan makes the spacing between plants the same and planting one planting hole for one seed. In addition, the use of medicines was also reduced by 1.7 liters, because with the existence of better soil processing equipment, sanitation, drainage and irrigation, it could reduce the number of pests and diseases that attack rice plants. Meanwhile, the amount of labor required in the planting and harvesting process for Planting Season 2 of 2018 also decreased by 16 hok, because by using technology (alsintan) the farmer's labor was replaced by machines. So that the agricultural machinery can also overcome the problem of the scarcity of labor available at the research location.

\subsection{Rice Farming Costs}

According to Supriyono (2000), costs are the cost of the cost or used to earn income, which will be used to deduct income. Cost analysis is performed to determine the total cost obtained from all costs used during the production process. Costs are grouped into 2, namely fixed costs and variable costs. Fixed costs are costs that are fixed and still incurred. Fixed costs have nothing to do with the quantity of goods produced. Meanwhile, variable cost is the cost incurred which is variable / not fixed depending on the area of the farm. If the farming area is extensive, it will cost more (Soekartawi, 1995).

Fixed costs in rice farming include taxes, irrigation and agricultural equipment depreciation costs, while rice farming variable costs include costs of production facilities, labor costs, and other costs. Fixed costs and variable costs of rice farming (Planting Season 2 of 2014) are converted to the rupiah value in 2018 by calculating annual inflation, and it is known that the amount of inflation from 2014 to 2018 is $19 \%$. The costs of farming in Planting Season 2 of 2014 and Planting Season 2 of 2018 can be seen in the following table.

Tabel 2. The Average Cost of Rice Farming, Planting Season 2 of 2014 and Planting Season 2 of 2018 at Gapoktan Tani Mandiri

\begin{tabular}{lrr}
\hline \multirow{2}{*}{ No. Description of Cost Proportion } & \multicolumn{2}{c}{ Hectares } \\
\cline { 2 - 3 } 1 & Planting Season 2 of 2014 & Planting Season 2 of 2014 \\
1.1 Taxes & 190.400 & 214.167 \\
1.2 Agricultural tools & & \\
1.3 Hoe & 20.000 & 20.000 \\
1.4 Sprayer & 60.000 & 60.000 \\
1.5 Sickle & 6.000 & 6.000 \\
1.6 Irrigation & 135.858 & 201.250 \\
Total Fixed Costs & 412.258 & 501.417 \\
Variable Costs & & \\
2.1 Rice seeds & 786.392 & 700.583 \\
2.2 Fertilizer & & \\
2.2.1 Urea & 617.313 & 640.333 \\
2.2.2 Ponska & 887.244 & 895.833 \\
2.2.3 SP36 & 516.063 & 528.333 \\
2.3 Pesticide & & \\
2.3.1 Matador & 141.908 & 93.333 \\
2.3.2 Sitop & 147.957 & 84.083 \\
2.3.3 Score 250 EC & 117.989 & 67.167 \\
2.4 Labor & & \\
2.4.1 Tillage & 1.507 .333 & 1.500 .000 \\
2.4.2 Planting & 2.502 .967 & 1.205 .833 \\
2.4.3 Fertilization & 307.020 & 352.500 \\
2.4.4 Weeding & 1.705 .667 & 1.753 .333 \\
2.4.5 Spraying & 309.400 & 410.000 \\
2.4.6 Harvest & 2.510 .900 & 2.258 .333 \\
Total Variable Costs & 12.058 .151 & 10.489 .667 \\
\hline Total cost & $\mathbf{1 2 . 4 7 0 . 4 0 9}$ & $\mathbf{1 0 . 9 9 1 . 0 8 3}$ \\
\hline
\end{tabular}


So it can be concluded that there is a difference or decrease in production costs from before using technology and corporate farming systems (Planting Season 2 of 2014) to after using technology and corporate farming systems (Planting Season 2 of 2018), which is IDR $1,479,326$ or $13 \%$.

\subsection{Comparative Analysis of Production and Income Levels}

Farming acceptance is the result obtained by farmers from their farming. Revenue obtained from production results multiplied by the selling price obtained from farming (Soekartawi, 1995). The revenue obtained by rice farmers comes from the sale of the rice harvest.

Farming income is the difference between costs incurred and revenue earned (Tjakrawiralaksana, 1983). The amount of income received is remuneration for labor, family working capital used and management carried out by all family members. The income received by farmers from a production result is the total revenue minus the total costs incurred in the production process. Production and income during Planting Season 2 of 2014 and Planting Season 2 of 2018 can be seen in the following table.

Tabel 3. Average Production and Income of Rice Farming Season 2 of 2014 and Planting Season 2 of 2018 at Gapoktan Tani Mandiri

\begin{tabular}{|c|c|c|c|}
\hline \multirow[b]{2}{*}{ No } & \multirow[b]{2}{*}{ Description } & \multicolumn{2}{|c|}{ Hectares } \\
\hline & & $\begin{array}{l}\text { Planting Season } \\
2 \text { of } 2014\end{array}$ & $\begin{array}{l}\text { Planting Season } \\
2 \text { of } 2014\end{array}$ \\
\hline 1 & $\begin{array}{l}\text { Production } \\
(\mathrm{Kg})\end{array}$ & 6670 & 8675 \\
\hline 2 & $\begin{array}{l}\text { Farming } \\
\text { Acceptance }\end{array}$ & Rp. 30.016 .950 & Rp. 39.037.500 \\
\hline 3 & $\begin{array}{l}\text { Farming } \\
\text { Costs }\end{array}$ & Rp. 12.470 .409 & Rp. 10.991.083 \\
\hline 4 & $\begin{array}{l}\text { Farm } \\
\text { Income }\end{array}$ & Rp. 17.546.541 & Rp. 28.046.417 \\
\hline
\end{tabular}

The price of GKP for rice during the planting season 2 of 2014 (Rp. 3,765/kg) was converted to the price of GKP in 2018, which was Rp. $4,500 / \mathrm{kg}$. So it can be seen that there is a difference in production results from before using technology and corporate farming systems (Planting Season 2 of 2014) and after using technology and corporate farming systems (Planting Season 2 of 2018), which is $2005 \mathrm{Kg}$ or $23 \%$. This means that using technology and a corporate farming system can increase rice production by $23 \%$.

The difference in income before using technology and corporate farming systems (Planting Season 2 of 2014) and after using technology and corporate farming systems (Planting Season 2 of 2018) is IDR 10,499,876/ha or $37 \%$. This means that using technology and a corporate farming system can increase the income of rice farmers by $37 \%$. This shows that the Dalangan Village Independent Farmer Gapoktan rice farming using technology and a corporate farming system has a positive impact on farmers' income.

Paired Sample T Test was carried out on rice production and income before (Planting Season 2 of 2014) and After (Planting Season 2 of 2018) to find out the difference between the average yields of rice production before the application of technology and corporate farming and the average yields. rice production after the application of technology and corporate farming. In the results of the Paired Sample T Test for rice production, the Sig. 0.000 is smaller than the value of 0.05 , so Ho is rejected $\mathrm{H} 1$ is accepted, which means that there is a significant difference between the average rice production before and after the application of technology and corporate farming. $\mathrm{H} 1$ is a condition where $\mu 1>\mu 2$, which means that the average rice production after the application of technology and corporate farming is greater than the average rice production before the application of technology and corporate farming. In the results of the Paired Sample T Test, rice income, the value of Sig. 0.000 is smaller than the value of 0.05 , so Ho is rejected $\mathrm{H} 1$ is accepted, which means that there is a significant difference between the average rice income before and after the application of technology and corporate farming. $\mathrm{H} 1$ is a condition where $\mu 1>\mu 2$, which means that the average rice income after the application of technology and corporate farming is greater than the average rice income before the application of technology and corporate farming.

\section{Conclusion}

Based on the research that has been conducted with the title "Comparison of Production Levels and Income of Rice Farming Using Technology and Corporate Farming", a case study on Gapoktan Tani Mandiri in Dalangan Village, Tawangsari District, Sukoharjo Regency, Central Java, can be concluded as follows: 
a. There was a significant increase in production yields from before using the technology and corporate farming system (Planting Season 2 of 2014), which was $6670 \mathrm{~kg} / \mathrm{ha}$ after using the technology and corporate farming system (Planting Season 2 of 2018) of $8675 \mathrm{~kg} / \mathrm{ha}$, which was accompanied by with a $13 \%$ reduction in production costs.

b. There was a significant increase in income from before using the technology and corporate farming system (Planting Season 2 of 2014) of Rp. 17,546,541/ha after using the technology and corporate farming system (Planting Season 2 of 2018) reaching Rp. 28,046,417/ha.

c. Factors that affect the increase in production and income of rice farming at Gapoktan Tani Mandiri include: (1) there is a rotating schedule for rice varieties, (2) young seeds are planted between the ages of 15-20 days, so that more tillers (with improved drainage conditions ), (3) better soil cultivation using alsintan, so that the availability of nutrients is better, (4) the resulting straw is smoother, thus accelerating the decomposition process, (5) the same spacing because using alsintan, (6) one planting hole one seedling (with alsintan), so that the growth of rice plants is more optimal because there is no competition for nutrients, (7) the number of planting holes is more, because there is land consolidation that eliminates bunds or boundaries between collectors, (8) the number of workers is more a little, thereby reducing the cost of labor wages, (9) farming is managed by corporations simultaneously or simultaneously.

\section{Reference}

Arikunto, S. 2010. Prosedur Penelitian Suatu Pendekatan Praktik. Jakarta: Rineka Cipta.

[BALITBANG]. Badan Penelitian dan Pengembangan Pertanian. 2015. Inovasi Teknologi Agroindustri: Inovasi Teknologi Membangun Ketahanan Pangan dan Kesejahteraan Petani. litbang.pertanian.go.id. Halaman 385$391.400 \mathrm{hlm}$.

Dinas Pertanian 2000. Panduan Rice Estate and Corporate Farming. Bandung.
Drs. R. A. Supriyono, S.U, 2000, Sistem Pengendalian Manajemen, Edisi Pertama, Yogyakarta: BPFE-Yogyakarta

Mardikanto, Totok. 1993. Penyuluhan Pembangunan Pertanian. Sebelas Maret Univercity Press. Surakarta. Press. 211 hal.

Miarso, Yusufhadi. (2007). Menyemai Benih Teknologi Pendidikan. Jakarta: Kencana.

Setiawan, Iwan. 2008. Collective Farming sebagai Alternatif Strategi Pemberdayaan Petani. Bandung: Unpad.

Soekartawi. 1995. Analisis Usaha Tani. Jakarta : UI Press.

Subarna dan Trisna. 2013. Apresiasi Petani Terhadap Teknologi dan Penyuluh Pertanian Dalam Peningkatan Produksi Padi. Teknologi Alsintan , 40-56.

Tjakrawiralaksana, Abbas dan Haji Muhamad Cuhaya Soeriaatmadja. 1983. Usahatani. Proyek Pengadaan Buku Pendidikan Menengah Kejuruan, Jakarta. 